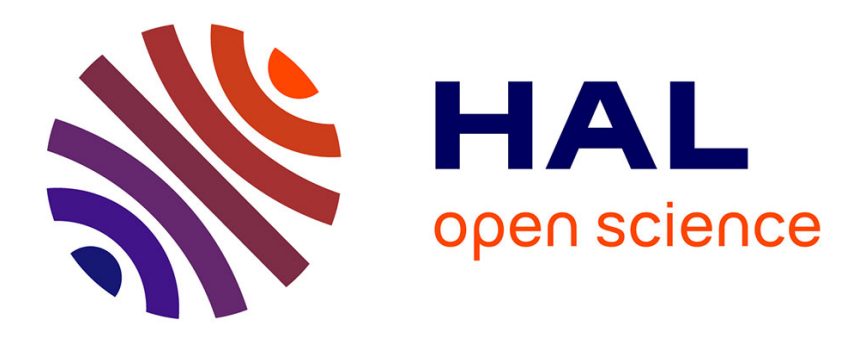

\title{
The Consequences of Laughter in Aeschines' Against Timarchos
}

\author{
Deborah Kamen
}

\section{To cite this version:}

Deborah Kamen. The Consequences of Laughter in Aeschines' Against Timarchos. Archimède: archéologie et histoire ancienne, 2018, Archimède $n^{\circ} 5$. Archéologie et histoire ancienne, 5, pp.4956. halshs- 01825146

\section{HAL Id: halshs-01825146 https://shs.hal.science/halshs-01825146}

Submitted on 29 Jun 2018

HAL is a multi-disciplinary open access archive for the deposit and dissemination of scientific research documents, whether they are published or not. The documents may come from teaching and research institutions in France or abroad, or from public or private research centers.
L'archive ouverte pluridisciplinaire HAL, est destinée au dépôt et à la diffusion de documents scientifiques de niveau recherche, publiés ou non, émanant des établissements d'enseignement et de recherche français ou étrangers, des laboratoires publics ou privés. 


\section{ARCHIMÈDE N5

DOSSIER THÉMATIQUE : HUMOEROTICA

1 Ruby BLONDELL et Sandra BOEHRINGER

Humour et érotisme dans I'Antiquité grecque et romaine. Introduction au dossier

7 Marina HAWORTH

The Wolfish Lover: The Dog as a Comic Metaphor in Homoerotic Symposium Pottery

24 James ROBSON

Whoring, Gaping and Hiding Meat: The Humour of Male-on-Male Sexual Insults in Aristophanes' Knights

\section{Carmen DAMOUR}

De qui se moque-t-on? Les travestis sur la scène de l'Assemblée des femmes d'Aristophane

\section{Deborah KAMEN}

The Consequences of Laughter in Aeschines' Against Timarchos

57 Yvonne RÖSCH

Hunting Hares and Lovers: Socrates' Playful Lesson in Xenophon, Memorabilia III, 11

\section{Eugene 0'CONNOR}

Aroused by Laughter: Martial's Priapic Humor

83 Sandra BOEHRINGER with the artistic collaboration of Marjolaine FOURTON Not a Freak but a Jack-in-the-Box: Philaenis in Martial, Epigram VII, 67

\section{Michel BRIAND}

Des mœurs sexuelles des Sélénites (Lucien, Histoires vraies, I, 22) : entre satire queer et constructionnisme incarné, le sexe qui donne à rire et à penser

108 ACTUALITÉ DE LA RECHERCHE : DES FEMMES PUBLIQUES. GENRE, VISIBILITÉ ET SOCIABILITÉ DANS L'ANTIQUITÉ GRECQUE ET ROMAINE

185 VARIA

\section{LA CHRONIQUE D’ARCHIMÈDE}

\section{@creative (1) (1) (0)}




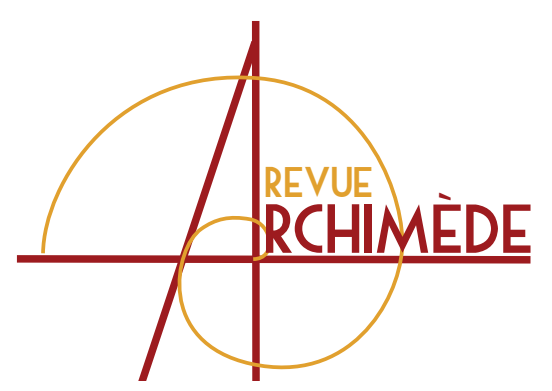

ARCHÉOLOGIE ET HISTOIRE ANCIENNE

\title{
THE CONSEQUENCES OF LAUGHTER IN AESCHINES' AGAINST TIMARCHOS
}

\author{
Deborah KAMEN
}

Associate Professor of Classics

Department of Classics

University of Washington

dkamen@uw.edu

\section{ABSTRACT}

In Aeschines' Against Timarchos, the orator tells the jury about occasions on which sexual innuendos uttered by or about Timarchos provoked laughter in the Assembly (Aeschines, Against Timarchos, 80-84). Arguing that the Assembly's laughter not only affirmed Timarchos' reputation but also drowned out his voice, I demonstrate that Aeschines coopts this laughter in order to reinforce the civic silence that was Timarchos' due as a male prostitute.

\section{KeYWORDS}

Male prostitution, double entendre, homoeroticism, consequential laughter, silence, atimia.
That is, the laughter was made "consequential," in that it ultimately contributed to Timarchos' conviction and disenfranchisement (atimia).
Dans son Contre Timarque, I'orateur Eschine raconte au jury les moments où Timarque a provoqué le rire de l'Assemblée en raison de sous-entendus sexuels dans ses propos ou dans les propos le concernant (Contre Timarque, 80-84). Après avoir montré que le rire de I'Assemblée non seulement contribue à renforcer la réputation de Timarque mais vient également parler à sa place, cet article met en évidence la façon dont Eschine utilise ce rire pour souligner le silence civique, seule «parole » que mérite Timarque en tant que prostitué. Par conséquent, ce rire a des effets concrets et contribue, en définitive, à la condamnation de Timarque et à sa déchéance civique (atimia).
MotS-CLÉS

Prostitution masculine, équivoque, homoérotisme, rire et effet du rire, silence, atimia. 
In his speech Against Timarchos [1], Aeschines charges the defendant Timarchos with having spoken in the Assembly despite being a male prostitute. About halfway through the speech, there is a peculiar passage in which Aeschines tells the jury about a handful of words, uttered by or about Timarchos, that on previous occasions had provoked laughter in the Assembly (Aeschines I, 80-85). In this article, I first explore why these words were so funny, drawing on the observation that they are double entendres connoting homoeroticism [2] - what we might call "humoerotic" language. I explore, secondly, what the immediate effect of the Assembly's laughter was, and thirdly, how Aeschines co-opted this laughter and its effects in the service of Timarchos' conviction. Ultimately, I argue this laughter was what Stephen Halliwell calls "consequential" - that is, it had the consequence of bringing pain, shame, or harm on its target beyond the laughter's immediate context [3].

But first, some background on the speech is in order. In $346 \mathrm{BCE}$, an Athenian embassy, including both Demosthenes and Aeschines, was sent to Philip of Macedon to discuss the terms of a peace treaty. When the ambassadors returned to Athens, they presented the Athenian people with the terms of the agreement, and the Athenians adopted what was known as the Peace of Philokrates, named after the main negotiator of the treaty. A second embassy, with the same men, was then sent to Macedon in order for Philip to ratify the treaty. When this second embassy returned, Demosthenes, supported by his friend Timarchos, brought charges against Aeschines for misconduct on the embassy. In 345 $\mathrm{BCE}$, Aeschines, in order to delay the impending trial against him, brought against Timarchos a dokimasia rhêtorôn ("examination of orators") [4], alleging (among other things) that Timarchos had been a prostitute and was therefore automatically excluded from speaking in front of the Assembly. Aeschines ultimately won his case against Timarchos, rendering Timarchos disenfranchised (atimos), and buying Aeschines some time to prepare his defense [5].

\section{WHAT'S SO FUNNY?}

It was in the midst of this serious case about disenfranchisement (atimia) that Aeschines told his stories about the Assembly's laughter. In order to determine why he did this - and what effects it had - it is necessary to figure out what made the Assembly laugh.

In the first instance, Aeschines says that the year Timarchos was on the Boule (347/346 BCE), whenever he spoke in the Assembly [6], mentioning "the repair of 'walls' or of a 'tower,' or that someone 'was led off' (apegeto) somewhere, immediately you shouted and laughed, and you yourselves said the name (epônumian) of the deeds you know he committed" ( $\mathrm{I}, 80)$. What did Timarchos likely mean here? In speaking of walls and towers, he was referring, presumably, to a need to repair the city's defensive structures, possibly in anticipation of war with Philip [7]. And in talking about people being "led off", he may have been referring to the arrest of traitors, since apagô is a technical term for arrest [8].

But clearly the subject of defensive walls and towers, and the arrest of traitors, was not what made the audience holler with laughter. As has been suggested by others, Timarchos' seemingly
[1] Henceforth I will refer to this speech as Aeschines I.

[2] On the double entendres in this passage, see, e.g., DE BRUYN 1995: 147-148, FISHER 2001 ad loc.

[3] HalliWell 1991: 282. On "consequential laughter," see Halliwell 1991, Halliwell 2008. (Halliwell briefly discusses this passage of Aeschines I in 1991: 293 and 2008: 236.)

[4] On the dokimasia rhêtorôn, with special attention to Aeschines I, see FEYEL 2009: 198-207.
[5] On atimia, see KAMEN 2013: ch. 7. On atimia for male prostitutes, see HALPERIN 1990 and WALLACE 1998.

[6] There are multiple textual difficulties here. DILTS'

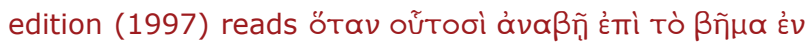

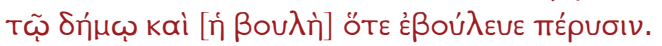

[7] FISHER 2001 ad loc.

[8] FiSHER 2001 ad loc. For apagô as "arrest," see Liddell-Scott-Jones [= LSJ] IV. 
innocuous words must have had a humorous double meaning. Building upon commentators and translators of this text, I will demonstrate that what made these words laughable was their sexual connotations [9].

First, the walls, towers, and arrests. The areas around city walls were popular places for sexual encounters, especially with prostitutes [10]. Thus in Aristophanes' Knights, the Sausage Seller says that he sells sausages - and sometimes sex - at the gates of the city walls $(1242,1247)$, a spot where female prostitutes (pornai) are also found (1400, 1401). Towers, like walls, were also spots for sex, and of course towers also had phallic connotations, as they do now [11]. And finally, apagô, in addition to meaning "arrest", also had the secondary sense of "lead off for sexual purposes" [12]. Athenaeus relates a story that Sophocles led off (apegage) a pretty boy outside the city walls to have sex with him (The Learned Banqueters, XIII, 604d). Not only is the verb apagô used here, but this is another example of the sexual activity that took place around city walls. It is unclear if this boy was a prostitute, but he did steal Sophocles' cloak after their rendezvous (604e).

These words, then, all of which call to mind semi-illicit sex, caused the people to shout, laugh, and say the "name" of Timarchos' deeds. In order to maintain the appearance of propriety [13], Aeschines does not spell out here what exactly this "name" is, but his choice of the word epônumia is significant. A little later in the speech, Aeschines uses the same word when he says that Homer "hides the love [of Patroklos and Achilles] and the name (epônumian) of their friendship" (I, 142). Not quite "the love that dare not speak its name," but that seems to be the gist.

[9] Cf. Adams 1919: 67 n. 2, CARey 2000: 51 n. 86, who suggest that the meaning of these double entendres is lost on modern readers.

[10] HALPERIN 1990: 91; DAVIDSON 1997: 80 (suggesting that "walls" and "tower" might connote specifically the area of the Kerameikos); FISHER 2001 (on "walls" and "tower")

[11] Cf. AdAms 1919: 67 n. 2, who suggests that "tower" here connotes women's apartments.

[12] AdAMS 1919: 67 n. 2; FISHER 2001 ad loc.; cf. LSJ I.3. [13] Aeschines repeatedly says that he does not want to use bad language: see, e.g., I, 38, 70. On propriety in the orators, see CAREY 1999; cf. Miner 2015.

[14] "Bumsy" is Dover's formulation (1978: 75). The kinaidic meaning of Batalos derives either from a certain effeminate aulos-player named Batalos or from a slang term for anus. See further FISHER 2001 ad I, 126, KAMEN 2014, and SAPSFORD 2017: 82-87.
Aeschines also uses the word epônumia repeatedly of Demosthenes' nickname Bat(t)alos (I, 126, 131, 164; On the Embassy, 99), which with two taus can be translated as something like "Babbler," with one tau, "Bumsy" [14]. According to Aeschines, Demosthenes earned this epônumia not from his childhood stammering (as Demosthenes himself claimed), but from his lack of andreia or masculinity (anandria), his shamelessness (aischrourgia), and especially his gender deviance [15] (kinaidia) (I, 131; On the Embassy, 99). Epônumia is also used by Aeschines three times, in quick succession, in reference to the names of places where Timarchos allegedly sold his body for sex [16]. I would argue, then, that by using the word epônumia in I, 80 - a word which (at least in this speech) is charged with homoeroticism - Aeschines can discreetly suggest what the people said without spelling it out: namely, that Timarchos is a male prostitute (pornos). In fact, Aeschines confirms this nickname later in the speech by quoting the jury's hypothetical response to a mention of Timarchos: "Which Timarchos? The pornos?" (I, 130) [17]. Once again, however, Aeschines manages to avoid uttering the name in his own voice.

Following this, Aeschines claims, in good rhetorical fashion, that he could tell many more stories about things that happened in the past, but instead he will focus on something that transpired at a particular Assembly meeting, the one that prompted him to make a proclamation (epangelia) challenging Timarchos to a dokimasia rhêtorôn (I, 81). At this Assembly meeting, the council of the Areopagos happened to be present to weigh in on a resolution put forth by Timarchos [18]. While we do not know the exact substance of the proposal - it had

[15] For the kinaidos as a gender deviant, see WINKLER 1990: 46-47.

[16] Aeschines says that Demosthenes demanded that he provide the name (epônumias) of every lodging where Timarchos allegedly offered sexual services. Aeschines replies that a lodging does not give its name (epônumias) to its inhabitants; instead, inhabitants give the name (epônumias) of their pursuits to the lodging $(\mathrm{I}, 123)$.

[17] On pornos as Timarchos' nickname, see FISHER 2001: 56-57 and ad loc.

[18] The Areopagos here seems to be functioning in an ad-hoc capacity. Some scholars believe (on the basis of this passage) that the Areopagos investigated infringements of building regulations, but WALLACE 1989: 120 (followed by FISHER 2001 ad loc.) argues that the superintendence of buildings was instead the job of the ten astunomoi. DE BRUYN 1995: 147-149 calls the involvement of the Areopagos here an extraordinary intervention, likely brought about at the Assembly's request. 
something to do with "oikêseis" (houses) - it seems that Timarchos had proposed that the city deal with the deserted and falling-down houses on or around the Pnyx [19]. It is unclear how big a project this was going to be [20].

In any event, Aeschines tells the jury that an Areopagos member named Autolykos informed the Assembly that the Areopagos had rejected Timarchos' proposal [21]. Autolykos then said to the people: "Don't be surprised if Timarchos is more experienced in the desolate spots (erêmias) on the Pnyx than the Areopagos is" (I, 82). If we assume that this was a comment innocent of any double entendres [22], Autolykos was simply saying that Timarchos was experienced with the Pnyx the meeting place of the Assembly - as someone who was actively engaged in politics [23]. And by "desolate spots", he was presumably referring to those areas Timarchos proposed to redevelop. In fact, similar language is used by Xenophon in his Ways and Means, when he suggests that metics be allowed to build houses in Athens, since there are "many desolate spots (erêma) for houses and building sites (oikopeda) within the city walls" (II, 6) [24]. The Assembly, however, read sexual innuendos into Autolykos' words. Aeschines says that everyone applauded and said that Autolykos spoke the truth, since Timarchos was indeed "experienced" with the deserted parts of the Pnyx - that is, places (again, like walls and towers) frequently used for sexual encounters [25].

But Autolykos' double entendres did not stop there. Not understanding the reason for the people's uproar (or at least feigning not to), he next said that the Areopagos cut Timarchos some slack, allowing for the possibility that "perhaps Timarchos thought that in this quiet (hêsuchiai) there would be little expense for each of you" (I, 83). By this, Autolykos was likely referring to Timarchos' suggestion that, during peacetime (a time of relative quiet), redevelopments on the Pnyx would be easier for the state to afford [26]. But, as Aeschines tells the jurors, Autolykos provoked still greater uproar and laughter among the Assembly with the words "quiet" and "little expense" (I, 83). For the Assembly members, these words clearly had other connotations: "quiet" likely suggested desolate sexual meetingplaces [27], and "little expense" called to mind the low cost of Timarchos' sexual services [28]. In fact, the very mention of expense at all - coupled with the low price - might have connoted the cheapest of prostitutes in Athens: we might think, for example, of the pornoi and pornai whom literature records "bending over" for a measly three obols [29].

According to Aeschines, Autolykos next spoke of "building sites" (oikopedôn) [30] and "cisterns" (lakkôn), and once again the people were not able to contain themselves ( $\mathrm{I}, 84)$. What Autolykos was presumably talking about - again, innocently (or not) - was the building sites and cisterns that needed to be cleared for the proposed redevelopment of the Pnyx. What did the people find so funny about this? The word oikopeda at first glance seems innocuous; it is the same word that we see, for example, in the Xenophon passage mentioned above. In this context, however, the word might
[19] For evidence that this was the content of Timarchos proposal, see the Scholia ad Orationem in Timarchum, 179 (commenting on Aeschines I, 81), along with DE BRUYN 1995: 148-149, CAREY 2000: 52 n. 88, and FISHER 2001 ad loc. DAVIDSON 1997: 306-307 says that oikêseis here connotes primitive (pre-urban) dwellings; but cf. FISHER 2001 ad loc. The word oikêsis also comes up twice in Aeschines I, 123.

[20] See Fisher 2001: 64, who says that it is unclear whether this was "merely a relatively minor tidying up of unsavoury areas on the fringes of the Pnyx, or the beginnings of what would become the major rebuilding of Pnyx III," the latter of which likely took place in the 330s (Rotroff 1996; see also FISHER 2001 ad loc.).

[21] Aeschines does not explain why Timarchos' proposal was rejected, likely because it's not germane to his argument.

[22] Cf. WinkLER 1990: 52, who argues that Autolykos "has it both ways" (i.e. playing it straight while also making deliberate double entendres).

[23] See CAREY 2000: 52 n. 90 and Fisher 2001 ad loc.
[24] Xenophon might even have had in mind proposals similar to that of Timarchos, since he uses some of the very same language we see in this passage.

[25] AdAMS 1919: 68 n. 2; DAVIDSON 1997: 79; CAREY 2000: 52 n. 90. Cf. the reputation of the Lykavettos Hill as a place for homoerotic trysts (Theopompos, PCG vii fr. 30). The slopes of Mount Hymettos may have been used for the same purpose (see LANGDON 2004: 205).

[26] AdAMS 1919: 69 n. 3; CAREY 2000: 52 n. 91.

[27] CAREY 2000: 52 n. 91; FISHER 2001 ad loc.; SPATHARAS 2006: 381. For this meaning of hêsuchia, see $L S J$ II.

[28] CAREY 2000: 52 n. 91; Fisher 2001 ad loc.; SPATHARAS 2006: 381.

[29] On the commodification of the pornê, see DAVIDSON 1997 (especially ch. 4) and KURKE 1997. On the price of three obols for kubda, see Athenaeus, The Learned Banqueters, X, 442a and XIII, 580d.

[30] FISHER 2001 ad loc. renders this term as "building-plots, or uncompleted, or partially ruined or abandoned, buildings on a site". 
have been humorous for a number of reasons. First of all, it evoked an image of derelict buildings that were suitable for surreptitious sexual acts, including prostitution [31]. Secondly, in that the word referred to the foundations or "bottoms" of buildings, it had the potential to suggest other kinds of bottoms [32]. And thirdly, oikopeda may have been amusing for its auditory similarity to the word orchipeda ("testicles") [33].

The sexual connotations of lakkos, on the other hand, are perhaps more obvious [34]: cisterns, with their wide openings for collecting rainwater, easily call to mind bodily orifices, especially large ones. In fact, lakkos and related words are often used with this sexual sense [35]. For example, Athenaeus describes a hetaira whose services were purchased by two men, one of whom insulted her by calling her "lakkos" (The Learned Banqueters, XIII, 585a) [36]. A related insult is lakkoprôktos, "cistern-assed," with a sense similar to the more common adjective euruprôktos, "wide-assed". In the case of Timarchos, then, the word lakkos likely called to mind wide-open anuses [37], and by association, Timarchos' insatiable desire to be penetrated [38]. The word lakkos may have been additionally humorous because of its similarity to the word lakkopeda, meaning "scrota" [39]. This association might have been especially primed by the coupling of lakkos with oiko-peda in this passage.

\section{THE LAUGHTER AND ITS IMMEDIATE EFFECTS}

We see, then, that the people in the Assembly laughed because all of these words connoted sex

[31] DAVIDSON 1997: 306; FISHER 2001 ad loc. On homoerotic encounters in the ruins of the Athenian general Kimon's estate, see Kratinos, PCG iv fr. 160.

[32] CAREY 2000: 53 n. 92.

[33] AdAMS 1919: 71 n. 1; Spatharas 2006: 381. On orchipeda, see HENDERSON 1991: 124.

[34] As FISHER 2001 ad loc. notes, this is the most explicit sexual reference Aeschines makes in this passage.

[35] For some examples, see HeNDERSON 1991: 210.

[36] See also OLson 2010: 379: "I.e. because her vagina was so large and loose."

[37] CAREY 2000: 53 n. 92.

[38] DAVIDSON 1997: 79; FISHER 2001 ad loc.; WORMAN 2008: 346

[39] AdAMS 1919: 71 n. 1; Spatharas 2006: 381. Lakkos is also found as part of a compound adjective lakkoscheas, meaning "with hanging scrotum".
- and in particular, male homoeroticism and male prostitution. One effect of this laughter, if not necessarily its design, was to attest to, and thereby solidify, Timarchos' sexual reputation [40]. Another likely effect was to shut Timarchos up. In fact, any kind of uproar (thorubos) [41], including (and perhaps especially) laughter, had the potential to quiet a speaker, whether in the Assembly or in the courts [42]. Sometimes this uproar was enough not only to momentarily silence a speaker, but even to remove him physically from the speaker's platform (bêma).

For example, in Plato's Protagoras, Socrates says that when someone speaks in the Assembly on a topic about which he isn't knowledgeable, the people laugh at him and scorn him until, overcome by the uproar, he gives up trying - and, in some cases, the police-archers actually drag him from the platform (aphelkusôsin) or kick him out of the Assembly (exarôntai) (319c). In Xenophon's Memorabilia, we learn that when Plato's brother Glaukon was a very young man (not yet twenty), he would routinely get up to speak in the Assembly, making a laughingstock of himself and getting dragged (helkomenon) from the speaker's platform (III, 6, 1). And in a passage earlier in Against Timarchos, Aeschines says that there is no use trying to drive away (apelaunein) certain men from the bêma, since they have no sense of shame (I, 34).

We are never told that Timarchos was dragged from the speaker's platform, but he was laughed at when he spoke of walls and towers, which likely shut him up at least temporarily. Moreover, Timarchos was sometimes silenced even when he wasn't the one speaking. After the Assembly members laughed at Autolykos' double entendres - and

[40] RYDBERG-Cox 2000: 425-426; FISHER 2001 ad I, 80. See also the Scholia ad Orationem in Timarchum, 184 (commenting on Aeschines I, 83), which asserts that the people made a ruckus "suspecting that Timarchus was a pornos".

[41] On thorubos in the courts, see BERS 1985, LANNI 1997; thorubos in the Assembly, see TACON 2001, VILLACÈQUE 2013: 268-277 and passim; in both, MONTIGLIO 2000: 144-151. On the important role of "citizen spectators" in democratic Athens (whether in the theater, courts, or Assembly), see VILLACÈQUe 2013.

[42] On laughter as a means of silencing one's opponent, see Spatharas 2006. On thorubos more generally silencing a speaker, see BERS 1985: 9 and MONTIGLIO 2000: 148. For example, on one occasion when Demosthenes tried to speak in the Assembly, Aeschines and Philokrates apparently jeered at him, causing everyone to laugh and not to listen to him (Demosthenes, On the False Embassy, 23). 
therefore (indirectly) at Timarchos himself - a man named Pyrrandros stepped forward and asked if the people were not ashamed to laugh in the presence of the Areopagos. Aeschines tells us that the people threw Pyrrandros out (exeballete), replying aggressively (hubolambanontes) [43] that they knew they shouldn't laugh, but that the truth was so strong, it prevailed over all rational calculations (I, 84). Effectively, then, the people did to Pyrrandros what they would have done to Timarchos if Timarchos had been speaking. That is, even though Timarchos was not the one personally dragged off the bêma, he was nonetheless silenced, in that all further discussion of his proposal was shut down.

\section{HUMOR AND ITS LONG-TERM CONSEQUENCES}

In addition to quieting Timarchos and confirming his reputation, the Assembly's laughter had consequences that went beyond these meetings, thanks in large part to Aeschines. What Aeschines manages to do in Against Timarchos is to coopt this earlier laughter in the service of his own larger, longerterm goals: namely, securing the atimia - and therefore the civic silencing - of Timarchos [44]. He does this in two main ways [45].

First, Aeschines introduces the Assembly's laughter as "evidence" for Timarchos' sexual reputation, saying "I take this [46] to be the testimony (marturian memarturêsthai) offered to you by the Athenian people, whom it is not good for you to convict of false witness (pseudomarturiôn)"
(I, 85). It should be pointed out that Aeschines had very little concrete evidence that Timarchos was a prostitute: he could find no witnesses who would testify either to hiring Timarchos for sex or to seeing Timarchos engaged in prostitution. In the face of this complete lack of testimony - and the defense's repeated insistence that Aeschines produce witnesses [47] - Aeschines found a clever solution: he framed the Assembly's laughter as the testimony of the demos, using the same language to describe it that one would use to introduce an actual deposition (e.g. marturia) [48]. He even says that questioning this "testimony" would be akin to charging someone with perjury, using the technical term for public lawsuits (graphai) for false testimony: namely, pseudomarturiôn. Technically, of course, the Assembly members could not be charged with perjury [49], but by presenting them as a "witness," their "testimony" is automatically granted extra weight [50].

Secondly, and somewhat paradoxically, in addition to presenting the Assembly's laughter as testimony for the jury to consider, he also conflates the current jurors with the Assembly members [51], employing a technique found throughout the orators [52]. He prefaces the stories of laughter by saying that he knows that, even if (in a hypothetical world) he had not been allowed to offer up an accusation (as he is now), the jurors still would have voted that Timarchos was a prostitute, "because you" - that is, you the jurors - "have spoken freely and told me" (I, 80). But when have they done this? According to Aeschines, it was when Timarchos spoke of walls and towers in the Assembly and "immediately you shouted (eboate)
[43] See KURKE 2013 on hupolabôn (ephê) as a marker of aggressive speech.

[44] See also DAvidson 1997: 262-263; Spatharas 2006: 382. On atimia as civic silencing, see MonTIGLIO 2000: 116; AlLen 2000: 230; HeAth 2005: 180.

[45] In addition, Aeschines' telling of these stories presumably made the jury laugh, thus "solidif[ying] the jurors' connection to him as a speaker promulgating social norms against a deviant who breaks them" (MINER 2015: 136).

[46] The verb Aeschines uses here is hubolambanô, perhaps linking himself to the Assembly members who replied aggressively to Pyrrandros (hupolambanontes, I, 84).

[47] E.g. Aeschines I, 71, 87, 119, 160.

[48] See also Spatharas 2006: 382: "Aeschines is here using a previous audience's laughter as a witness of Timarchus' disreputable life."
[49] On this point, see also FISHER 2001 ad loc.

[50] On the value of witness testimony in the Athenian courts, see, e.g., Mirhady 2002. As Mirhady points out, the demos (generally in the form of the jurors) is frequently called upon as a witness (2002: 264).

[51] On the conflation of the two in this speech, see FISHER 2001: 215. He points out (2001: 215-216, 222), however, that when convenient, Aeschines separates the two (e.g. in I, 85).

[52] A debate exists about how best to interpret these instances of conflation of jury and Assembly: HANSEN 1990: 220-221 argues that the two could be assimilated because of an overlap in personnel attending both (i.e. ordinary citizens); ОBER 1996: 117-119 suggests that assimilation is possible because both the courts and the Assembly were understood by synecdoche to be parts of the whole citizen body; and WOLPERT 2003 reads assimilation as a rhetorical fiction that allowed the Athenians to imagine the demos' power as transcending time and space. 
and laughed, and you yourselves (autoi) said the name of the deeds you know he committed" (I, 80) [53]. By using the second-person plural both of the present jurors and of the past Assembly, Aeschines links the two groups, suggesting, with the emphatic autoi, that the latter is equivalent to the former.

But the assimilation does not stop there. Throughout this passage, Aeschines continues to use the second-person plural to refer to the members of the Assembly, thus cementing the conflation between the two groups [54]. And when he is done telling the stories, he concludes by saying that it would be strange "if, on the one hand, you yourselves (autoi) shout (boate) the name of the deeds you know he committed when I say nothing, but on the other, when I do say something" - that is, now, in this court case - "you forget" $(I, 85)$ [55]. The verbal similarities of the men clause in I, 85 to what Aeschines says in I, 80 are striking (autoi; the

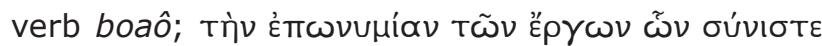

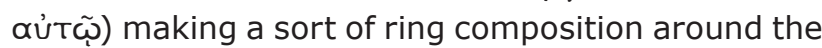
stories, wherein the jury and Assembly members are one and the same. The de clause then brings the "you" back from the (past) Assembly into the world of the (present) jurors. At the same time, since the two groups are notionally the same, Aeschines can say, and does say, that it would be inconsistent for the jurors not to vote in the courtroom the way "they" did in the court of public opinion.
Through both of these strategies, then, Aeschines is able to harness, and make maximal use of, the Assembly's laughter. And to good effect: doing so helps him to convict Timarchos, thereby extending his opponent's silence from temporary to permanent. In fact, there are even reports that Timarchos hanged himself out of despair after losing his suit [56]. While this is unlikely to have been his literal fate, it does reflect the social death he experienced through his conviction. At least for Timarchos, then, humoerotica had serious consequences [57].

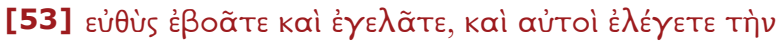

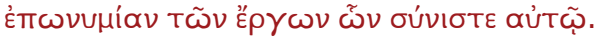

[54] E.g., "You applauded" (I, 82), "not understanding your uproar" ( $I, 83)$, "uproar from you" (I, 83), "Pyrrandros came out to censure you" (I, 84), "you (emphatic: humeis) kicked him out" (I, 84).

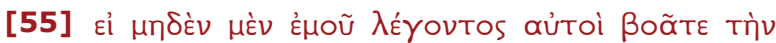

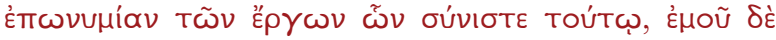

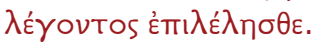

[56] See Plutarch, Moralia, 480F. FISHER 2001: 22 n. 7 thinks that Plutarch's report is "a dramatic exaggeration" of Demosthenes' claim that Aeschines "removed" (anêirêke) and "destroyed" (apôlesen) his opponent (see Demosthenes, On the False Embassy, 2 and 285, respectively).

[57] I would like to thank the following for their comments and suggestions (all errors are of course my own): Ruby Blondell, Sandra Boehringer, Sarah Levin-Richardson, Tom Sapsford, Kate Topper, and the journal's two anonymous reviewers.

Adams, Charles D., 1919, The Speeches of Aeschines, Cambridge, Mass. (Loeb Classical Library).

AlLen, Danielle S., 2000, The World of Prometheus: The Politics of Punishing in Democratic Athens, Princeton.

Bers, Victor, 1985, «Dikastic thorubos », in Paul A. Cartledge \& F. David Harvey (ed.), Crux: Essays in Greek History Presented to G. E. M. de Ste. Croix on his 75th Birthday, London, p. 1-15.

CareY, Chris, 1999, «Propriety in the Attic Orators», in Francesco De Martino \& Alan H. Sommerstein (ed.), Studi sull' eufemismo, Bari, p. 371-391.

Carey, Chris, 2000, Aeschines, Austin.

Davidson, James, 1997, Courtesans and Fishcakes: The Consuming Passions of Classical Athens, London.

De BRUYN, Odile, 1995, La compétence de l'Aréopage en matière de procès publics. Des origines de la « Polis 》 athénienne à la conquête romaine de la Grèce (vers 700-146 avant J.-C.), Stuttgart (Historia Einzelschriften 90).

DrLTs, Mervin, 1997, Aeschines: Orationes, Leipzig - Stuttgart (Bibliotheca scriptorum Graecorum et Romanorum Teubneriana).

Dover, Kenneth, 1978, Greek Homosexuality, London - New York [tr. fr. Suzanne Saïd, Homosexualité grecque, Grenoble, 1982].

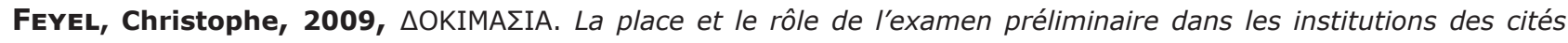
grecques, Nancy.

FrSHER, Nick (ed.), 2001, Aeschines: Against Timarchos, Oxford. 
Halliwell, Stephen, 1991, « The Uses of Laughter in Greek Culture », Classical Quarterly 41, p. 279-296.

Halliwell, Stephen, 2008, Greek Laughter: A Study of Cultural Psychology from Homer to Early Christianity, Cambridge.

HALPERIN, David, 1990, One Hundred Years of Homosexuality: And Other Essays on Greek Love, New York - London [tr. fr. Isabelle Châtelet, Cent ans d'homosexualité et autres essais sur l'amour grec, Paris, 2000].

Hansen, Mogens H., 1990, « The Political Powers of the People's Court in Fourth-Century Athens », in Oswyn Murray \& Simon Price (ed.), The Greek City from Homer to Alexander, Oxford, p. 215-243.

HeATH, John, 2005, The Talking Greeks: Speech, Animals, and the Other in Homer, Aeschylus, and Plato, Cambridge.

Henderson, Jeffrey, 1991, The Maculate Muse: Obscene Language in Attic Comedy, $2^{\text {nd }}$ ed. (1 ${ }^{\text {st }}$ ed. 1975), Oxford.

KAMEN, Deborah, 2013, Status in Classical Athens, Princeton.

Kamen, Deborah, 2014, «Kina[i]dos: A Pun in Demosthenes' On the Crown? », Classical Quarterly 64, p. 405-408.

KURKe, Leslie, 1997, «Inventing the Hetaira: Sex, Politics, and Discursive Conflict in Archaic Greece », Classical Antiquity 16, p. 106-150.

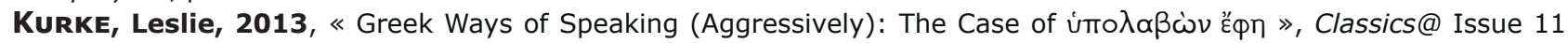
(http://chs.harvard.edu/CHS/article/display/5138).

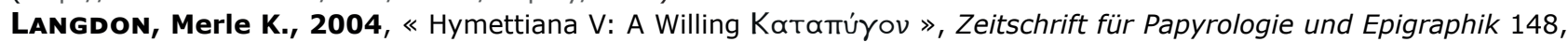
p. 201-206.

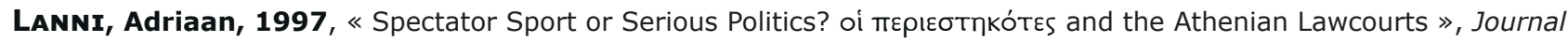
of Hellenic Studies 117, p. 183-189.

MINeR, Jess, 2015, « Risk and Reward: Obscenity in the Law Courts at Athens », in Dorota Dutsch \& Ann Suter (ed.), Ancient Obscenities: Their Nature and Use in the Ancient Greek and Roman Worlds, Ann Arbor, p. 125-150.

MirhadY, David C., 2002, « Athens' Democratic Witnesses », Phoenix 56, p. 255-274.

Montrglio, Silvia, 2000, Silence in the Land of Logos, Princeton.

OвER, Josiah, 1996, The Athenian Revolution: Essays on Ancient Greek Democracy and Political Theory, Princeton.

Olson, S. Douglas, 2010, Athenaeus, The Learned Banqueters, vol. VI. Cambridge, Mass. (Loeb Classical Library).

Rotroff, Susan I., 1996, « Pnyx III: Pottery and Stratigraphy », in Björn Forsén \& Greg Stanton (ed.), The Pnyx in the History of Athens, Helsinki, p. 35-40.

RYdeR-Cox, Jeffrey A., 2000, « An Unusual Exclamation in Aeschines' Against Timarchus (1.73) », Mnemosyne 53, p. $419-430$.

SAPSFORD, Thomas, 2017, The Life of the Kinaidoi, Dissertation, University of Southern California.

Spatharas, Dimos, 2006, «Persuasive $\Gamma E \wedge \Omega \Sigma$ : Public Speaking and the Use of Laughter », Mnemosyne 59, p. 374-387.

TACON, Judith, 2001, « Ecclesiastic thorubos: Interventions, Interruptions, and Popular Involvement in the Athenian Assembly », Greece \& Rome 48, p. 173-192.

Villacèque, Noémie, 2013, Spectateurs de paroles! Délibération démocratique et théâtre à Athènes à l'époque classique, Rennes.

WALLACE, Robert W., 1989, The Areopagos Council, to 307 B.C, Baltimore.

WALLACE, Robert W., 1998, « Unconvicted or Potential 'átimoi' in Ancient Athens », Dike 1, p. 63-78.

WinkLer, John, 1990, The Constraints of Desire: The Anthropology of Sex and Gender in Ancient Greece, London New York [tr. fr. Sandra Boehringer \& Nadine Picard, Désir et contraintes en Grèce ancienne, Paris, 2005].

Wolpert, Andrew 0., 2003, « Addresses to the Jury in the Attic Orators », American Journal of Philology 124, p. 537-555.

Worman, Nancy, 2008, Abusive Mouths in Classical Athens, Princeton. 